\title{
Potential Impact of BioField Treatment on Atomic and Physical Characteristics of Magnesium
}

\author{
Mahendra Kumar Trivedi ${ }^{1}$, Rama Mohan Tallapragada ${ }^{1}$, Alice Branton ${ }^{1}$, Dahryn Trivedi ${ }^{1}$, Gopal Nayak ${ }^{1}$, Omprakash Latiyal ${ }^{2}$ and Snehasis \\ Jana ${ }^{2 *}$ \\ ${ }^{1}$ Trivedi Global Inc., 10624 S Eastern Avenue Suite A-969, Henderson, NV 89052, USA \\ ${ }^{2}$ Trivedi Science Research Laboratory Pvt. Ltd., Hall-A, Chinar Mega Mall, Chinar Fortune City, Hoshangabad Rd., Bhopal- 462026, Madhya Pradesh, India
}

\begin{abstract}
Magnesium (Mg), present in every cell of all living organisms, is an essential nutrient and primarily responsible for catalytic reaction of over 300 enzymes. The aim of present study was to evaluate the effect of biofield treatment on atomic and physical properties of magnesium powder. Magnesium powder was divided into two parts denoted as control and treatment. Control part was remained as untreated and treatment part received biofield treatment. Both control and treated magnesium samples were characterized using X-ray diffraction (XRD), surface area and particle size analyzer. XRD data showed that biofield treatment has altered the lattice parameter, unit cell volume, density, atomic weight, and nuclear charge per unit volume of treated magnesium powder, as compared to control. In addition, the crystallite size of treated magnesium was significantly reduced up to $16.70,16.70$, and $28.59 \%$ on day 7,41 and 63 respectively as compared to control. Besides this, the surface area of treated magnesium powder was increased by 36.5 and $10.72 \%$ on day 6 and 72 respectively, whereas it was reduced by $32.77 \%$ on day 92 as compared to control. In addition, biofield treatment has also altered the particle sizes $d_{10}, d_{50}$, and $d_{99}$ (size, below which 10,50 , and $99 \%$ particles were present, respectively) as compared to control. Overall, data suggest that biofield treatment has substantially altered the atomic and physical properties of treated magnesium powder.
\end{abstract}

Keywords: Biofield treatment; Magnesium powder; X-ray diffraction; Fourier transform infrared; Particle size; Surface area

\section{Introduction}

Magnesium ( $\mathrm{Mg}$ ) is the third most abundant metal in the earth's crust. It exists in the form of hexagonal closed packed (HCP) crystal structure. Magnesium is the fourth most abundant mineral in the human body, which are responsible for various metabolic reactions and biological mechanisms. A normal human body contains about 22-26 grams of magnesium, in which $60 \%$ is present in skeleton, $39 \%$ in intracellular medium, and $1 \%$ in extracellular compartment. Furthermore, the main source of energy for living cells i.e. adenosine triphosphate (ATP) must require magnesium ions for their biological activity [1]. In addition, magnesium is essential for plants in chlorophyll synthesis and photosynthesis [2]. Although the magnesium is found in many food ingredients, but it is usually present in very low levels [3]. Thus, deficiency of magnesium is likely common among geriatric [4], obese, diabetics, and alcoholic people [5]. Deficiency of the magnesium in human body, known as hypomagnesaemia that causes many diseases such as osteoporosis, diabetes, and heart disease [6,7]. Currently, magnesium deficiency can be overcome by increase of magnesium concentration in diet or through oral supplements. Nevertheless, in oral supplement of magnesium, the dissolution, absorption, bioavailability, and permeability plays a major role. It was reported that dissolution and bioavailability of minerals are closely related to its crystal structure, crystallite size, and physical properties such as particle size and surface area [8]. Recently, dissolution, absorption and bioavailability of magnesium is improved by using various kind of magnesium-salts such as magnesium oxide, magnesium chloride, magnesium sulphate, and magnesium citrate $[9,10]$. Besides this, magnesium is also utilized in synthesis of Grignard reagent, which is primarily responsible for the formation of carboncarbon bonds, carbon-silicon bonds, carbon-boron bonds, carbonphosphorus bonds in synthesis of various pharmaceutical products [11]. After considering the vast importance of magnesium in life of living organisms, authors wish to investigate an economically safe approach that could be beneficial to modify the atomic and physical properties of magnesium powder.
In physics, the energy is considered as the ability to do work; which fundamentally interrelates with matter as $\mathrm{E}=\mathrm{mc}^{2}$ (Einstein's famous equation). However the energy can be considered as a field of force which effectively interacts with any matter at a distance and cause action. Researchers have confirmed that bio magnetic fields are present around human body, which have been evidenced by electromyography (EMG), electrocardiography (ECG) and electroencephalogram (EEG) [12]. Scientists have postulated that it is due to the flow of bioelectricity (generated from heart, brain functions or due to the motion of charged particles such as protons, electrons, and ions) in the human body. As per the basic fundamental law in physics, when an electrical signal passes through any material, a magnetic field is generated in the surrounding space [13]. Hence, a magnetic field is created along with the bioelectricity in human body, known as bio magnetic field. Due to this, a human has ability to harness the energy from environment/ universe and can transmit into any object (living or non-living) around the Globe. The object(s) always receive the energy and responded into useful way that is called biofield energy. This process is termed as biofield treatment. Mr. Trivedi's biofield treatment is known as Trivedi Effect. Mr. Trivedi's biofield treatment is known to alter the physical, structural and atomic level in various metals [14-16] and ceramics $[17,18]$ in material science. Additionally, biofield treatment has significantly studied in the field of microbiology [19-21], biotechnology $[22,23]$, and agriculture [24-26]. Recently, it was reported that biofield treatment had increased the particle size by six fold and enhanced the crystallite size by two fold in zinc powder [27]. In another report,

*Corresponding author: Snehasis Jana, Trivedi Science Research Laboratory Pvt. Ltd., Hall-A, Chinar Mega Mall, Chinar Fortune City, Hoshangabad Rd. Bhopal- 462026, Madhya Pradesh, India, Tel: +91-755-6660006; Email: publication@trivedisrl.com

Received July 29, 2015; Accepted August 03, 2015; Published August 12, 2015

Citation: Trivedi MK, Tallapragada RM, Branton A, Trivedi D, Nayak G, et al. (2015) Potential Impact of Biofield Treatment on Atomic and Physical Characteristics of Magnesium. Vitam Miner 3: 129.

Copyright: () 2015 Trivedi MK, et al,. This is an open-access article distributed under the terms of the Creative Commons Attribution License, which permits unrestricted use, distribution, and reproduction in any medium, provided the original author and source are credited. 
Citation: Trivedi MK, Tallapragada RM, Branton A, Trivedi D, Nayak G, et al. (2015) Potential Impact of Biofield Treatment on Atomic and Physical Characteristics of Magnesium. Vitam Miner 3: 129.

biofield treatment has shown the significant effect in carbon allotropes, where the unit cell volume was decrease by $1 \%$ and crystallite size was increased by $100 \%$ [28]. Based on the outstanding result achieved by biofield treatment on metals and ceramics, an attempt was made to evaluate the effect of biofield treatment on atomic and physical properties of magnesium powder.

\section{Experimental}

The magnesium powder was purchased from MEPCO, India. The sample was equally divided into two parts, considered as control and treated. Treated group was in sealed pack and handed over to Mr. Trivedi for biofield treatment under laboratory condition. Mr. Trivedi provided the biofield treatment through his energy transmission process to the treated group without touching the sample. The control and treated samples were characterized using X-ray diffraction (XRD), surface area analyzer, and particle size analyzer at different time periods.

\section{X-ray diffraction study}

$\mathrm{XRD}$ analysis of control and treated magnesium powder was carried out on Phillips, Holland PW 1710 X-ray diffractometer system, which had a copper anode with nickel filter. The radiation of wavelength used by the XRD system was $1.54056 \AA$. The data obtained from this XRD were in the form of a chart of $2 \theta$ vs. intensity and a detailed table containing peak intensity counts, $d$ value $(\AA)$, peak width $\left(\theta^{\circ}\right)$, relative intensity (\%) etc. Additionally, PowderX software was used to calculate lattice parameter and unit cell volume of magnesium powder samples.

Weight of the unit cell was calculated as, atomic weight multiplied by the number of atoms present in a unit cell. Density of the unit cell was computed as follows:

$$
\text { Density }=\frac{\text { Weight of unit cell }}{\text { Volume of unit cell }}
$$

Atomic Weight $=[($ Number of total proton $\times$ mass of proton $)$ + (Number of total neutron $\times$ mass of neutron $)+($ Number of total electron $\times$ mass of electron)]

Atomic weight in $\mathrm{g} / \mathrm{mol}$ was calculated as multiplying the atomic weight by the Avogadro number $\left(6.023 \times 10^{23}\right)$. Total nuclear charge was calculated as the number of protons multiplied by charge on a proton $\left(1.6 \times 10^{-19} \mathrm{C}\right)$. Nuclear charge per unit volume was computed as follow:

$$
\text { Nuclear ch } \arg \text { e per unit volume }=\frac{\text { Total nuclear ch } \arg \text { e in an atom }}{\text { Volume of an atom }}
$$

The crystallite size $(\mathrm{G})$ was calculated by using formula:

$$
\mathrm{G}=\mathrm{k} \lambda /(\mathrm{b} \operatorname{Cos} \theta) \text {, }
$$

Here, $\lambda$ is the wavelength of radiation used, $b$ is full width half maximum (FWHM) and $\mathrm{k}$ is the equipment constant (0.94). Furthermore, the percent change in the lattice parameter was calculated using following equation:

$$
\% \text { change in lattice parameter }=\frac{\left[A_{\text {Treated }}-A_{\text {control }}\right]}{A_{\text {control }}} \times 100
$$

Where $\mathrm{A}_{\text {Control }}$ and $\mathrm{A}_{\text {Treated }}$ are the lattice parameter of treated and control samples respectively. Similarly, the percent change in all other parameters such as unit cell volume, density, atomic weight, nuclear charge per unit volume and crystallite size were calculated.

\section{Surface area analysis}

The surface area was measured by the Surface area analyzer, Smart SORB 90 based on Brunauer-Emmett-Teller (BET), which had a detection range of $0.20-1000 \mathrm{~m}^{2} / \mathrm{g}$. Percent changes in surface area were calculated using following equation:

$$
\% \text { change in surface area }=\frac{\left[S_{\text {Treated }}-S_{\text {control }}\right]}{S_{\text {control }}} \times 100
$$

Where, $S_{\text {Control }}$ and $S_{\text {Treated }}$ are the surface area of control and treated samples respectively.

\section{Particle size analysis}

Particle size of control and treated magnesium powder was evaluated using, laser particle size analyzer SYMPATEC HELOS-BF, which had a detection range of $0 \cdot 1-875 \mu \mathrm{m}$. The particle size data was collected in the form of a chart of particle size $v s$. cumulative percentage. Four parameters of particle sizes viz. $\mathrm{d}_{10} \mathrm{~d}_{50}$, and $\mathrm{d}_{99}$ (size below which $10 \%, 50 \%$ and $99 \%$ particles are present, respectively) were calculated from the particle size distribution curve. The percent change in particle size was calculated using following equation:

$$
\% \text { change in particle size, } d_{10}=\frac{\left[\left(d_{10}\right)_{\text {Treated }}-\left(d_{10}\right)_{\text {control }}\right]}{\left(d_{10}\right)_{\text {control }}} \times 100
$$

Where, $\left(\mathrm{d}_{10}\right)_{\text {Control }}$ and $\left(\mathrm{d}_{10}\right)_{\text {Treated }}$ are the particle size, $\mathrm{d}_{10}$ of control and treated samples respectively. Similarly, the percent change in particle size $d_{50}$ and $d_{99}$ were calculated.

\section{Results and Discussion}

\section{X-ray diffraction (XRD)}

XRD results of control and treated magnesium samples are presented in Table 1. It was found that that lattice parameter of unit cell was slightly increased by $0.08,0.07,0.05 \%$ on day 7,41 , and 63 respectively as compared to control. The increase in lattice parameter leads to increase the unit cell volume by $0.16,0.13$, and $0.09 \%$ on day 7, 41 and 63 respectively as compared to control. While the density was reduced by $0.16,0.13$ and $0.09 \%$ on day 7,41 and 63 respectively as compared to control (Figure 1). The decrease in density could be due to increase in unit cell volume in magnesium powder after biofield treatment. Furthermore, data exhibited that atomic weight of treated

\begin{tabular}{|c|c|c|c|c|c|c|}
\hline Group & $\begin{array}{l}\text { Lattice parameter } \\
(\AA)\end{array}$ & $\begin{array}{l}\text { Unit cell volume } \\
\left(\times 10^{-23} \mathrm{~cm}^{3}\right)\end{array}$ & Density (g/cc) & $\begin{array}{l}\text { Atomic weight } \\
(\mathrm{g} / \mathrm{mol})\end{array}$ & Nuclear Change per unit volume $\left(\mathrm{C} / \mathrm{cm}^{3}\right)$ & Crystallite size $(\mathrm{nm})$ \\
\hline Control, Day 0 & 3.2094 & 4.6525 & 1.7275 & 24.205 & 110892.80 & 87.16 \\
\hline Treated, Day 7 & 3.2120 & 4.6600 & 1.7248 & 24.244 & 110625.20 & 72.60 \\
\hline Treated, Day 41 & 3.2115 & 4.6586 & 1.7253 & 24.237 & 110675.07 & 72.60 \\
\hline Treated, Day 63 & 3.2109 & 4.6568 & 1.7260 & 24.228 & 110739.24 & 62.23 \\
\hline
\end{tabular}
magnesium was increased by $0.16,0.13$, and $0.09 \%$ on day 7,41 , and 63 respectively as compared to control. In addition, nuclear charge per unit volume was reduced by $0.24,0.20$, and $0.14 \%$ on day 7,41 , and 63 respectively as compared to control (Figure 2). It was previously reported that biofield treatment has altered the atomic weight and

Table 1: X-ray diffraction analysis of magnesium powder. 


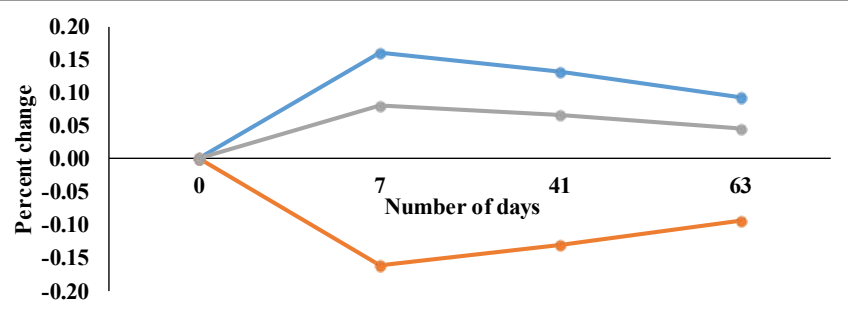

$\rightarrow$ Unit cell volume $\rightarrow$ Density $\rightarrow$ Lattice Parameter

Figure 1: Effect of biofield treatment on unit cell volume and density of magnesium powder.

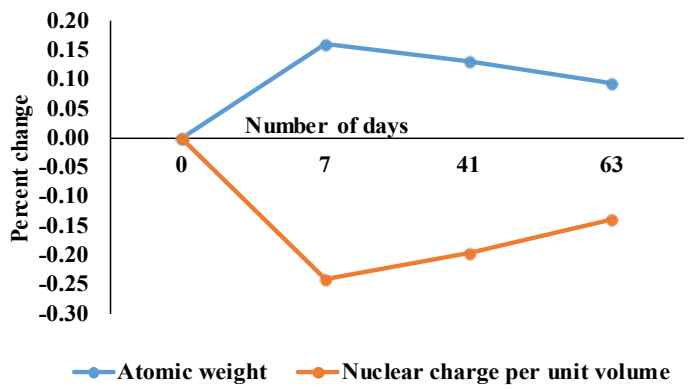

Figure 2: Effect of biofield treatment on atomic weight and nuclear charge per unit volume of magnesium powder.

nuclear charge per unit volume in iron, zinc and copper [27,28]. The change in atomic weight and nuclear charge per unit volume indicates that number of protons and neutron probably altered after biofield treatment. It could be possible if a weak reversible nuclear level reaction occurred in treated magnesium after biofield treatment. Thus, it is assumed that biofield treatment probably transferred the energy to magnesium atoms and that might cause these alteration at nuclear level [29]. Besides this, the crystallite sizes of control and treated magnesium powder were computed using Scherrer formula and presented in Table 1. Data showed that the crystallite size was decreased from 87.16 (control) to $72.60,72.60$, and $62.23 \mathrm{~nm}$ in treated magnesium sample on day 7,41 , and 63 , respectively. It suggests that crystallite size of treated magnesium powder was significantly reduced by $16.70,16.70$, and $28.60 \%$ on day 7,41 , and 63 , respectively as compared to control (Figure 3). It was previously reported that biofield treatment has reduced the crystallite size in cobalt $(\mathrm{Co})$, manganese $(\mathrm{Mn})$, and titanium (Ti) [27]. Moreover, the existence of severe lattice strains in treated magnesium are evidenced by the change in unit cell volume (Figure 1). Thus, it is assumed that presence of these internal strains may lead to fracture the grains into sub grains and decrease the crystallite size. Furthermore, it is demonstrated that the rate of dissolution may also be altered by choosing a suitable polymorph of a compound, which has low crystallinity or high amorphous phase and hence exhibits higher solubility [30]. Torrado et al. reported that solids with small crystallite size exhibits faster dissolution rate as compared to solids with higher crystallite size [31]. Thus, it is hypothesized that biofield treated magnesium powder may exhibit the higher dissolution rate as compared to control.

\section{Surface area analysis}

Surface area analysis of magnesium powder is illustrated in Table 2 and Figure 4. Data showed that surface area of treated magnesium powder was increased from $0.30 \mathrm{~m}^{2} / \mathrm{g}$ (control) to 0.41 and $0.33 \mathrm{~m}^{2} / \mathrm{g}$ on day 6 and 72 respectively, whereas it was decreased to $0.20 \mathrm{~m}^{2} / \mathrm{g}$ on day 92 as compared to control (Table 2). This indicates that surface area of treated magnesium powder was increased by 36.5 and $10.72 \%$ on day 6 and 72 respectively, whereas it was decreased by $32.77 \%$ on day 92 as compared to control (Figure 4). Our group previously reported that biofield treatment has significantly increased the surface area in zirconium oxide [32]. Besides, Noyes-Whitney proposed the relationship between rate of dissolution (R) and surface area (S) of a solid as following [33]:

$$
R=\frac{D S\left(C_{s}-C\right)}{L}
$$

Where, $\mathrm{D}$ is diffusion constant, $\mathrm{C}_{\mathrm{s}}$ and $\mathrm{C}$ are the concentration in the bulk dissolution medium and diffusion layer surrounding the solid, respectively, L is diffusion layer thickness. Thus, Noyes-Whitney equation, inferred that the rate of dissolution may be modified primarily by altering the surface area of the solid. Hence, it is assumed that biofield treated magnesium powder, having higher surface area may exhibit higher rate of dissolution as compared to control. This higher dissolution of a mineral in the human gastric fluid, make it easily available for absorption in the body, which may results into higher bioavailability as compared to control.

\section{Particle size analysis}

The effect of biofield treatment on particle sizes $d_{10}$ and $d_{50}$ was analyzed and results are presented in Table 3 and Figure 5. Data showed that smaller particle size $d_{10}$, was changed from $89.75 \mu \mathrm{m}$ (control) to $79.79,137.87,83.69$ and $76.79 \mu \mathrm{m}$ in treated magnesium powder on day $10,75,80$, and 98 , respectively (Table 3 ). It indicates that $d_{10}$ in treated sample was reduced by $11.09 \%$ on day 10 as compared to control, which might be responsible for increase in surface area. Our group previously reported that biofield treatment has induced energy milling in metal powder, which fractured the titanium and chromium powder [27]. Thus, it is hypothesized that reduction in particle size in magnesium powder could be due to energy milling induced through biofield treatment. Further, $\mathrm{d}_{10}$ was increased by $53.61 \%$ as compared

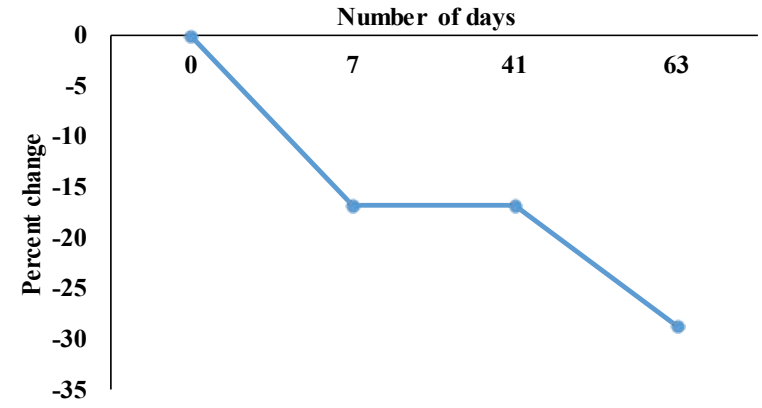

Figure 3: Effect of biofield treatment on crystallite size of magnesium powder.

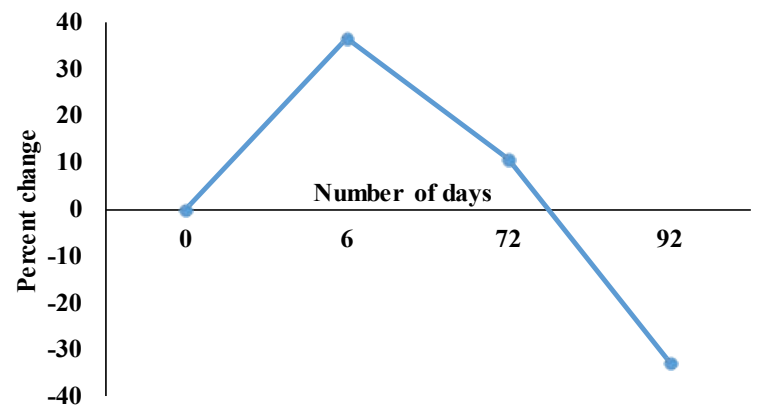

Figure 4: Effect of biofield treatment on surface area of magnesium powder. 
Citation: Trivedi MK, Tallapragada RM, Branton A, Trivedi D, Nayak G, et al. (2015) Potential Impact of Biofield Treatment on Atomic and Physical Characteristics of Magnesium. Vitam Miner 3: 129.

Page 4 of 5

\begin{tabular}{|c|c|}
\hline Group & Surface Area $\left(\mathrm{m}^{2} / \mathbf{g}\right)$ \\
\hline Control, Day 0 & $\mathbf{0 . 2 9 7 5}$ \\
\hline Treated, Day 6 & $\mathbf{0 . 4 0 6 1}$ \\
\hline Treated, Day 72 & $\mathbf{0 . 3 2 9 4}$ \\
\hline Treated, Day 92 & $\mathbf{0 . 2 0 0 0}$ \\
\hline
\end{tabular}

Table 2: Surface area analysis of magnesium powder.

\begin{tabular}{|c|c|c|c|}
\hline Groups & $\mathbf{d}_{\mathbf{1 0}}(\boldsymbol{\mu m})$ & $\mathbf{d}_{\mathbf{5 0}}(\boldsymbol{\mu m})$ & $\mathbf{d}_{\mathbf{9 9}}(\boldsymbol{\mu m})$ \\
\hline Control, Day 0 & 89.75 & 256.7 & 501.5 \\
\hline Treated, Day 10 & 79.79 & 260.7 & 502.3 \\
\hline Treated, Day 75 & 137.87 & 290.5 & 500.1 \\
\hline Treated, Day 80 & 83.69 & 261.5 & 498.4 \\
\hline Treated, Day 98 & 76.79 & 252.6 & 498.9 \\
\hline
\end{tabular}

$d_{10}, d_{50}$, and $d_{99}$, size below which 10,50 , and $99 \%$ particles are present, respectively Table 3: Particle size analysis of magnesium powder.

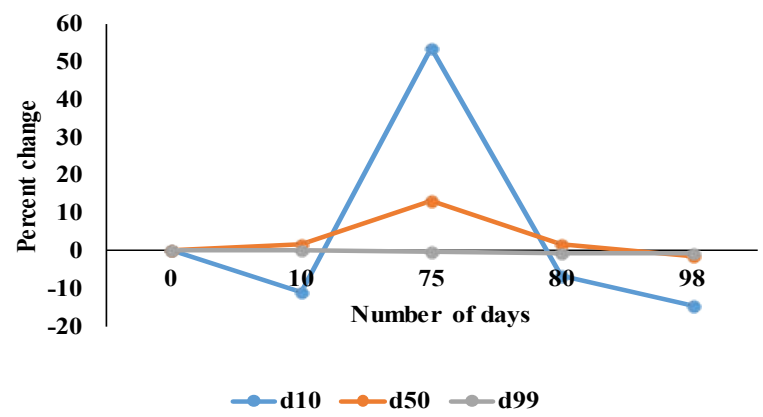

Figure 5: Effect of biofield treatment on particle size $d_{10}, d_{50}$, and $d_{99}$ of magnesium powder.

to control on day 75. It is possible that fresh surface generated through fracturing, possibly welded with each other and increased particle size [16]. Furthermore, $d_{10}$ was reduced by 6.75 and $14.44 \%$ on day 80 and 98 respectively as compared to control. In addition, average particle size, $\mathrm{d}_{50}$ was changed from $256.7 \mu \mathrm{m}$ (control) to 260.7, $290.5,261.5$, and $252.6 \mu \mathrm{m}$ in treated magnesium powder on day 10 , 75,80 , and 98 , respectively. It suggests that $d_{50}$ was increased by 0.16 , 13.17 , and $1.87 \%$ powder on day 10,75 , and 80 respectively, whereas it was slightly decreased by $1.59 \%$ as compared to control on day 98 (Figure 5). In addition, larger particle size $\mathrm{d}_{99}$ was reduced from $501.5 \mu \mathrm{m}$ (control) to $502.3,500.1,498.4$, and $498.9 \mu \mathrm{m}$ in treated magnesium powder on day $10,75,80$, and 98 , respectively (Table 3 ). It suggests that $d_{99}$ was not significantly changed after biofield treatment. Thus, the particle size data suggest that medium $\left(d_{50}\right)$ and smaller $\left(\mathrm{d}_{10}\right)$ size particles were more affected through biofield treatment as compared to large $\left(\mathrm{d}_{99}\right)$ particles. It was previously reported that biofield treatment has significantly altered the particle size in aluminium [15] and zinc powder [27]. Moreover, it is well established fact that particle size and surface area are having inverse relationship i.e. smaller the particle size, the larger the surface area. The increase in surface area on day 6 (Figure 4) can be correlated to reduction in particle size of smaller particles $\left(\mathrm{d}_{10}\right)$ on day 10 (Figure 5 ). Further, data showed that on day 72 surface area reduces up to $0.33 \mathrm{~m}^{2} / \mathrm{g}$ as compared to $0.41 \mathrm{~m}^{2} / \mathrm{g}$ i.e. found on day 6 , which may be due to increase in particle size $d_{10}$ and $d_{50}$. Furthermore, the reduction in particle size (after day 75) and surface area (after day 72 ) is contrary. It is possible that the fresh surfaces of the particles obtained after fracture got oxidized and which probably results into low surface area as compared to control [34]. Therefore, particle size and surface area result suggest that biofield treatment has altered the physical properties of magnesium powder.

\section{Conclusion}

In summary, the biofield treatment has significantly altered the atomic and physical properties of magnesium powder. XRD data revealed that biofield treatment has increased the unit cell volume and atomic weight up to $0.16 \%$ and reduced the nuclear charge per unit volume up to $0.24 \%$, as compared to control. The crystallite size of treated magnesium was significantly reduced up to $28.59 \%$ as compared to control. It is assumed that the internal strain induced by biofield treatment may fracture the crystallite and reduced crystallite size. Besides, the surface area of treated magnesium was increased up to $36.5 \%$ as compared to control. It is assumed that higher surface area and lower crystallite size in treated magnesium might exhibits the higher dissolution rate in human gastric fluid and may lead to increase the bioavailability of magnesium ions in the body.

\section{Acknowledgement}

Authors gratefully acknowledged to Dr. Cheng Dong of NLSC, Institute of Physics, and Chinese academy of Sciences for providing the facilities to use PowderX software for analyzing XRD data. Authors also would like to thank Trivedi science, Trivedi master wellness and Trivedi testimonials for their support during the work.

\section{References}

1. Erdman JW (2012) Present knowledge in nutrition. (10thedn). John Wiley \& Sons.

2. Maria-Jose M (2008) Chlorophylls - from functionality in food to health relevance. $5^{\text {th }}$ pigments in food congress- for quality and health. University of Helsinki.

3. Fine KD, Ana CAS, Porter JL, Fordtran JS (1991) Intestinal absorption of magnesium from food and supplements. J Clin Invest 88: 396-402.

4. Gums JG (2004) Magnesium in cardiovascular and other disorders. Ame J Health Syst Pharm 61: 1569-1576.

5. Purvis JR, Movahed A (1992) Magnesium disorders and cardiovascular diseases. Clin Cardiol 5: 556-568.

6. Sales CH, Lde FP (2006) Magnesium and diabetes mellitus: their relation. Clin Nutr 25: 554-562.

7. Guerrero-Romero F, Rodriguez-Moran M (2006) Hypomagnesemia, oxidative stress, inflammation, and metabolic syndrome. Diabetes Metab Res Rev 22 471-476.

8. Chereson R (2009) Bioavailability, bioequivalence, and drug selection. In: Makoid CM, Vuchetich PJ, Banakar UV (eds) Basic pharmacokinetics (1stedn) Pharmaceutical Press, London.

9. Herbert K, Thomas W, Peter M, Harald A, Klaus H, et al. (1998) Magnesium sulfate reduces intra- and postoperative analgesic requirements. AnesthAnalg 87: $206-210$

10. Gurley BJ, Wang P, Gardner SF (1998) Ephedrine-type alkaloid content of nutritional supplements containing Ephedra sinica (ma-huang) as determined by high performance liquid chromatography. J Pharm Sci 87: 1547-1553.

11. Maruyama K, Katagiri T (1989) Mechanism of the Grignard reaction. J Phys Org Chem 2: 205-213.

12. Zahra M, Farsi M (2009) Biofield therapies: Biophysical basis and biological regulations. Complement Ther Clin Pract 15: 35-37.

13. Maxwell JC (1865) A dynamical theory of the electromagnetic field. Phil Trans R SocLond 155: 459-512.

14. Trivedi MK, Patil S, Tallapragada RM (2012) Thought intervention through biofield changing metal powder characteristics experiments on powder characteristics at a PM plant. Future Control and Automation LNEE 173: 247-252.

15. Trivedi MK, Patil S, Tallapragada RM (2015) Effect of biofield treatment on the physical and thermal characteristics of aluminium powders. Ind Eng Manage 4: 151.

16. Trivedi MK, Patil S, Tallapragada RM (2013) Effect of biofield treatment on the 
Citation: Trivedi MK, Tallapragada RM, Branton A, Trivedi D, Nayak G, et al. (2015) Potential Impact of Biofield Treatment on Atomic and Physical Characteristics of Magnesium. Vitam Miner 3: 129.

physical and thermal characteristics of silicon, tin and lead powders. J Material Sci Eng 2: 125

17. Trivedi MK, Patil S, Tallapragada RM (2013) Effect of biofield treatment on the physical and thermal characteristics of vanadium pentoxide powder. J Material Sci Eng S11: 001.

18. Trivedi MK, Nayak G, Patil S, Tallapragada RM, Latiyal O (2015) Studies of the atomic and crystalline characteristics of ceramic oxide nano powders after biofield treatment. Ind Eng Manage 4: 161.

19. Trivedi MK, Patil S, Shettigar H, Gangwar M, Jana S (2015) Antimicrobial sensitivity pattern of Pseudomonas fluorescens after biofield treatment. J Infect Dis Ther 3: 222.

20. Trivedi MK, Patil S, Shettigar H, Bairwa K, Jana S (2015) Phenotypic and biotypic characterization of Klebsiellaoxytoca: An impact of biofield treatment. J Microb Biochem Technol 7: 203-206.

21. Mahendra KT, Shrikant P, Harish S, Mayank G, Jana S (2015) An effect of biofield treatment on Multidrug-resistant Burkholderiacepacia: A multihost pathogen. J Trop Dis 3: 167.

22. Patil S, Nayak GB, Barve SS, Tembe RP, Khan RR (2012) Impact of biofield treatment on growth and anatomical characteristics of Pogostemoncablin (Benth). Biotechnology 11: 154-162.

23. Altekar N, Nayak G (2015) Effect of biofield treatment on plant growth and adaptation. J Environ Health Sci 1: 1-9.

24. Shinde V, Sances F, Patil S, Spence A (2012) Impact of biofield treatment on growth and yield of lettuce and tomato. Aust J Basic Appl Sci 6: 100-105.
25. Lenssen AW (2013) Biofield and fungicide seed treatment influences on soybean productivity, seed quality and weed community. Agricultural Journal 8: 138-143.

26. Sances F, Flora E, Patil S, Spence A, Shinde V (2013) Impact of biofield treatment on ginseng and organic blueberry yield. Agrivita J Agric Sci 35.

27. Trivedi MK, Tallapragada RM (2008) A transcendental to changing metal powder characteristics. Met Powder Rep 63: 22-28, 31.

28. Trivedi MK, Tallapragada RM (2009) Effect of superconsciousness external energy on atomic, crystalline and powder characteristics of carbon allotrope powders. Mater Res Innov 13: 473-480.

29. Narlikar JV (1993) Introduction to cosmology. (2ndedn), Jones and Bartlett Inc. Cambridge University Press.

30. Raza K, Kumar P, Ratan S, Malik R, Arora S (2014) Polymorphism: The phenomenon affecting the performance of drugs. SOJ Pharm Pharm Sci 1: 10.

31. Torrado G, Fraile S, Torrado S, Torrado S (1998) Process-induced crystallite size and dissolution changes elucidated by a variety of analytical methods. Int J Pharm 166: 55-63.

32. Trivedi MK, Patil S, Tallapragada RM (2014) Atomic, crystalline and powder characteristics of treated zirconia and silica powders. J Material Sci Eng 3: 144

33. Dokoumetzidis A, Macheras P (2006) A century of dissolution research: From Noyes and Whitney to the biopharmaceutics classification system. Int J Pharm 321: 1-11.

34. Dhabade VV, Tallapragada RM, Trivedi MK (2009) Effect of external energy on atomic, crystalline and powder characteristics of antimony and bismuth powders. Bull Mater Sci 32: 471-479. 